\title{
Does Audit Committee Characteristics Promote Risk Management Practices in Nigerian Listed Firms?
}

\author{
Stephen A. Ojeka ${ }^{1}$, Alex Adeboye ${ }^{1} \&$ Olajide Dahunsi ${ }^{1}$ \\ ${ }^{1}$ Department of Accounting, College of Management and Social Sciences, Covenant University, Ota, Nigeria \\ Correspondence: Stephen A. Ojeka, Department of Accounting, College of Management and Social Sciences, \\ Covenant University, Ota, Nigeria.
}

Received: May 27, 2021

doi:10.5430/afr.v10n2p70
Accepted: May 24, 2021

Online Published: May 26, 2021

\begin{abstract}
There has been a huge and deluge of risk threatening industries at an unequalled magnitude in recent times. As such, the board of directors and senior executives are increasingly expected to manage their various organizations' risk portfolios, affecting their financial performance. This has led to the assigning of the risk assessment role to the audit committee. The board of directors and its audit committee play an essential function in Enterprise Risk Management (ERM) by building up the right condition or tone-at-the-top. Given the board's responsibilities for representing the interests of shareholders, it plays a vital role in overseeing management's approach to ERM. This study examined the relationship between audit committee characteristics and risk management of some selected listed firms in a developing country like Nigeria. The study used secondary data to describe the dependent variable (financial risk decomposed into credit risk and liquidity risk) and the explanatory variables (decomposed into audit committee accounting expertise, audit committee meetings, audit committee independence and audit committee gender). The study used pair sample t-test, student t-test, Pearson Moment Correlation and random panel data estimator for twenty (20) selected listed firms for 2012-2016. Findings indicate that there is a negative between audit committee accounting expertise and financial risk. This revealed that Accounting Expertise in Audit Committees are likely to involve in activities and practices to curb financial risk. In addition, the Audit committee meeting indicates a negative relationship with credit risk. Audit committee gender and audit committee independence have a negative effect on liquidity risk. Therefore, this study recommends that Audit committees embrace Enterprise Risk Management (ERM) to manage risks effectively across the organization. Risk management processes should be one of the major points of discussion during audit committee meetings.
\end{abstract}

Keywords: audit committee, risk management, financial risk, audit committee meetings and corporate governance

\section{Introduction}

In recent times, the volume and complexity of risk confronting industries are unequalled high (Beasley, 2010; Guo, 2017). As such, the board of directors and senior executives are increasingly expected to manage their various organizations' risk portfolios, affecting the firm's financial performance. This has led to the assigning of the risk assessment role to the audit committee. Disharoon (2015) asserted that the audit committee's basic role is to oversee the financial reporting process, the review procedure, the arrangement of internal controls and consistency with laws and directions. In addition, the committee analyses the consequences of the audit with management and external auditors, including matters required to be imparted to the panel under largely acknowledged inspecting gauges. Therefore, it is an essential piece in the internal control astound. The function that is going to be explained in this study is the risk assessment function. Jeanroy (2015) posited that a decent audit committee must comprehend the risk management procedure of the firm, and set a confirmation motivation and program to guarantee that the key risks of the body are secured, controlled and the risks themselves are this way limited.

The board of directors and its audit committee play an essential function in Enterprise Risk Management (ERM) by building up the right condition or tone-at-the-top, as seen in the survey conducted by Beasley (2010). In addition, given the board's responsibilities for representing the interests of shareholders, it plays a vital role in overseeing management's approach to ERM. Without their oversight, senior management may not embrace ERM. Thus, the audit committee's involvement in ERM is a critical component of effective governance and improved financial performance. 
However, Hamdan, Mushtaha, \& Al-Sartawi (2013) research discussed the absence of specificity in the audit committees' obligations, particularly in the audit committees' duty regarding oversight of enterprises risk management exercises. The contention is that the regulators of the audit committee failed to specify whether the audit committee ought to be the sole manager of risk management. As a result, audit committees are uncertain of their part in risk management oversight and are confounded regarding what kind of risks they ought to consider.

The credibility of the audit committees in risk management is increasingly being questioned in many countries worldwide. There is evidence that some of this criticism is based on the lack of specificity of the audit committee's function regarding risk management. The dispute is whether they should focus on financial risks or focus on non-financial reporting risks that may have financial reporting consequences. The problem of the credibility of the audit committee roles has drawn lots of attention. This has resulted in a lot of research work being conducted in that area. However, prior studies do not consider the specificity of the audit committees' role regarding risk management and its influence on financial performance. These studies mostly focus on the audit committee's internal audits, external audits and financial reporting. This can be seen in the study conducted by Disharoon (2015), where the audit committees' function is limited to oversight of financial reporting procedure, audit process, arrangement of internal control and compliance with rules and regulations. Sherman, Carey, \& Robert (2009)is in line with Disharoon's study. According to them, the audit committees' priority should be to ensure that financial projections are sound. However, none of these studies addresses the specific role the audit committee is expected to play in risk management. In addition, these studies were carried out in only the banking sector. This study thereby aims to fill the identified gap by carrying out the study across all sectors of the economy and emphasizing the audit committees' risk management role.

This study examined the relationship between audit committee characteristics and risk management of some selected listed firms in a developing country like Nigeria. The study used secondary data to describe the dependent variable (financial risk decomposed into credit risk and liquidity risk) and the explanatory variables (decomposed into audit committee accounting expertise, audit committee meetings, audit committee independence and audit committee gender). This study asserted that Audit Committee Accounting Expertise had a significant negative relationship between the accounting expertise in the audit committee and credit risk. This revealed that Accounting Expertise in Audit Committees are likely to involve in activities and practices to curb financial risk.

The remainder of this study was further organized into sections. Section 2 discussed the prior literature and hypotheses development, followed by a section on research methods. The subsequent sections focus on empirical findings and discussion of results, and the study is concluded in the last section.

\section{Literature Review and Hypothesis Development}

\subsection{Audit Committee Accounting Expertise and Financial Risk}

The need for accounting experts in audit committees became imperative after its inclusion in the SEC Code of 2011 (Ojeka, Fakile, Anijesu and Owolabi, 2016). The study further defined an accounting expert as an audit certified public/chartered accountant or has worked either in public accounting or for a public company as the chief financial officer or controller. DeZoort et al. (2002) revealed in their study that audit committees with accounting expertise always support auditors in case of auditors' management disputes. Audit committee members with accounting expertise have a strong influence on their ability to influence accounting decisions. In a study conducted by Farber, Huang and Mauldin (2016), audit committees with accounting expertise have lower liquidity risk. The study also revealed that firms with audit committees with accounting expertise would enhance the firms' market liquidity. Yatim (2009), as cited in Alzharani \& Aljaaidi (2015), revealed an insignificant association between audit committee accounting expertise and financial risk management. The study observed that audit committee members' possession of relevant accounting qualifications is not useful in identifying and mitigating risks. Furthermore, an audit committee associated with a high level of accounting expertise is likely to identify and mitigate credit and liquidity risks easily.

\section{$H_{0}$ : There is no significant relationship between audit committees accounting expertise and financial risk.}

\subsection{Audit Committee Meetings and Financial Risk}

Verschoor (2002) observed that the audit committee would usually meet a few hours before the board meeting in past times. This philosophy has changed due to their increasing responsibilities. They will be required to meet for a longer period to allow for more in-depth discussion. In 2002, The Code of Corporate Governance in Nigeria stated that the audit committee should meet at least three times in a year and also that the quorum for the meetings of the audit committee would depend on the number of members of the committee and should be specified in terms of reference of the committee (Owolabi and Dada, 2011). The audit committee should meet with the external auditors at 
least once a year, without the executive board members. The audit committee must meet regularly to consider urgent issues that aid an effective governance system. The time of meeting and frequency of their meetings should not be left loose. It is expected that the law should state categorically the minimum time of meeting in a year to ensure that adequate attention is given to all important issues to be addressed by the committee. A study conducted by Alzharani \& Aljaaidi (2015) revealed a significant negative association between audit committee meeting and risk management. KPMG (2013) suggests that audit committees should meet 4-5 times a year. In addition, they should have private-in camera meetings where no executives or auditors will attend. During such meetings, the members are meant to discuss the key financial risks facing the institution. When this is done regularly, it will enable the audit committee to monitor credit and liquidity risks effectively. This will prevent such risks from increasing. As such, this study suggests a positive association between audit committee meetings and financial risks.

$H_{0}$ : There is no significant impact of audit committees' meetings on financial risk.

\subsection{Audit Committee Independence and Financial Risk}

The proportion of non-executive directors in the committee signifies audit committees' independence. Audit committees are expected to be independent as lack of independence impairs the ability of the audit committee to monitor risks (Edogbanya and Kamardin, 2015). The independence of audit committees' members on the board tends to contribute to a high market value as they have an in-depth understanding of the risky nature of the firm. They also understand that shareholders appreciate genuine risk practices, which amounts to improved firms' market value (Kirkpatrick, 2009 as cited in Akhor and Oseghale, 2017). However, Alzharani \& Aljaaidi (2015) observed in their study that there exists no relationship between audit committee independence and risk management. Akhor and Oseghale (2017) also observed that companies with independent audit committees are less likely to have a low level of liquidity and credit risk, which connotes a low level of internal control problem in financial reporting.

$H_{0}$ : There is no significant relationship between audit committee independence and financial risk.

\subsection{Audit Committee Gender and Financial Risk}

Different studies have advocated the need for more female members in the audit committee. Abdullah, KuIsmali and Nachum (2015), as cited in Zango, Kamardin and Ishak (2016), revealed that shareholders prefer female audit committee members as they aid in creating economic value of information. The appointment of female audit committee members is likely to improve the audit committee independence and eventually improve shareholders wealth (Zalata, Tauringana and Tingbani (2018). Akhor and Oseghale (2017) observed that female directors sitting on the audit committee board have higher expectations regarding their responsibility and role on the board, which brings about better monitoring of the board. A study conducted by Zalata, Tauringana and Tingbani (2018) revealed that female audit committee members are generally more risk-averse than their male counterparts. As a result, there will be a low level of financial risks in such companies, as these female members will always try to mitigate both liquidity and credit risks. In addition, Zango, Kamardin and Ishak (2016) observed a significant positive relationship between audit committee gender and financial risk.

$H_{0}$ : There is no significant relationship between audit committee gender and financial risk.

\section{Research Methods}

This study is exploratory, and data was extracted from annual reports of some selected listed companies in Nigeria, which involve the audit committees' characteristics in terms of accounting expertise, meetings, independence and gender and financial risk management in terms of credit and liquidity risk firms. The judgmental sampling method was also adopted, and the sample size comprised 20 selected listed companies from various sectors of the economy. The study used pair sample t-test, student t-test, Pearson Moment Correlation and panel data for twenty (20) selected listed firms for the period 2012-2016 to examine the overall influence of audit committees' characteristics on the financial risk management of listed companies in Nigeria.

\subsection{Model Specification}

The mathematical expression of the effect of audit committees' characteristics of listed companies in Nigeria on financial risk management is stated as follows:

$C R=A C A E+A C M E+A C I+A C G E+S I Z E+L E V$

$L R=A C A E+A C M E+A C I+A C G E+S I Z E+L E V$

In regression, the model is expressed as follow:

$$
C R_{i t}=\beta_{0}+\beta_{1} A C A E_{i t}+\beta_{2} A C M E_{i t}+\beta_{3} A C I_{i t}+\beta_{4} A C G E_{i t}+S I Z E_{i t}+L E V_{i t}+\varepsilon_{i t}
$$


$L R_{i t}=\beta_{0}+\beta_{1} A C A E_{i t}+\beta_{2} A C M E_{i t}+\beta_{3} A C I_{i t}+\beta_{4} A C G E_{i t}+S I Z E_{i t}+L E V_{i t}+\varepsilon_{i t}$

Table 1. Variables' Description

\begin{tabular}{|c|c|c|}
\hline VARIABLES & ACRONYM & MEASUREMENT \\
\hline \multicolumn{3}{|l|}{ Dependent Variable } \\
\hline Credit Risk & $\mathrm{CR}$ & $\begin{array}{l}\text { It is measured using the credit rating or log of } \\
\text { maximum exposure to the company's credit risk. }\end{array}$ \\
\hline Liquidity Risk & LR & $\begin{array}{l}\text { Measured using a current ratio which is the ratio of } \\
\text { current assets to current liabilities }\end{array}$ \\
\hline \multicolumn{3}{|l|}{ Independent Variable } \\
\hline $\begin{array}{l}\text { Audit Committee Accounting } \\
\text { Expertise }\end{array}$ & $\mathrm{ACAE}$ & $\begin{array}{l}\text { It is measured by the number of audit committee } \\
\text { members with relevant accounting qualifications. }\end{array}$ \\
\hline Audit Committee Meetings & $\mathrm{ACME}$ & $\begin{array}{l}\text { It is measured by the number of meetings of the } \\
\text { audit committee in a year. }\end{array}$ \\
\hline Audit Committee Independence & $\mathrm{ACI}$ & $\begin{array}{l}\text { It is measured by the number of non-executive } \\
\text { directors in the audit committee. }\end{array}$ \\
\hline Audit Committee Gender & ACGE & $\begin{array}{l}\text { It is measured by the number of female members in } \\
\text { the audit committee. }\end{array}$ \\
\hline \multicolumn{3}{|l|}{ Control Variable } \\
\hline Firm size & SIZE & $\log 10$ of total assets \\
\hline Leverage & LEV & The ratio of total liabilities to total assets \\
\hline
\end{tabular}

Source: Field Study (2018)

\section{Analysis and Presentation of Results}

This section revealed the various analyses of results and presentations. The hypotheses stated were rectified and analyzed via descriptive statistics, correlation coefficient and static panel data estimators.

\subsection{Descriptive Analysis}

The descriptive statistics of the variables used in the analysis presented in Table 2 explains the mean, standard deviation, minimum and maximum value for the sample. The mean value of credit risk is 16.44 with a maximum value of 22.29 and a minimum value of value of 12.15 revealing a standard deviation of 2.790 thereby showing some degree of variability in the credit risk of organizations. While the mean value of Liquidity risk is 1.252. It had a maximum value of 5.767 and standard deviation of 0.673 revealing variation thereby showing some degree of variability in the liquidity risk of organizations. Audit Committee Accounting Expertise (ACAE) shows an average of 0.860, with maximum and minimum values of 3 and 0 respectively while the standard deviation is 0.752 .

Table 2. Descriptive Statistics for the Population

\begin{tabular}{lccccc}
\hline Variables & $\mathrm{N}$ & Mean & Standard Deviation & Minimum & Maximum \\
\hline$C R$ & 99 & 16.44 & 2.790 & 12.15 & 22.29 \\
$L R$ & 100 & 1.252 & 0.673 & 0 & 5.767 \\
$A C A E$ & 100 & 0.860 & 0.752 & 0 & 3 \\
$A C M E$ & 100 & 4.040 & 1.091 & 0 & 7 \\
$A C I$ & 100 & 2.920 & 0.367 & 0 & 3 \\
$A C G E$ & 100 & 0.820 & 0.757 & 0 & 3 \\
SIZE & 99 & 12.00 & 2.455 & 7.964 & 15.37 \\
LEV & 100 & 0.762 & 0.598 & 0 & 6.105
\end{tabular}

Source: Authors' Survey (2018)

Audit Committee Meetings (ACME) shows an average of 4.040, with minimum and maximum values of 0 and 7 respectively while the standard deviation is 1.091. Audit Committee Independence (ACI) exhibits a mean value of 
2.920. It has a standard deviation of 0.367 , with minimum and maximum values of 0 and 3 respectively. Audit Committee Gender (ACGE) shows a mean of 0.820. It has a standard deviation of 0.757 , with minimum value of 0 and maximum value of 3 .

\subsection{Correlation Analysis}

Table 3. Correlation Matrix Table

\begin{tabular}{lcccccc}
\hline & $A C A E$ & $A C M E$ & $A C I$ & $A C G E$ & SIZE & LEV \\
\hline$A C A E$ & 1 & & & & & \\
$A C M E$ & -0.0928 & 1 & & & & \\
$A C I$ & $0.206^{*}$ & 0.0640 & 1 & & & \\
$A C G E$ & -0.0760 & 0.191 & 0.131 & 1 & 1 & \\
SIZE & $0.337^{* * *}$ & $0.257^{*}$ & 0.149 & -0.0314 & 0.0960 & 1 \\
LEV & 0.0319 & 0.0625 & 0.0871 & 0.148 & & \\
\hline
\end{tabular}

Source: Authors' Survey (2018)

${ }^{*} p<0.05,{ }^{* *} p<0.01,{ }^{* * *} p<0.001$

Table 3 reveals the Pearson correlation matrix for the independent variables adopted in the analysis. The Table indicates low correlation among the variables, which indicate no evidence of multicollinearity in the models.

\subsection{Findings}

Table 4 illustrated the multiple linear regression analysis to examine the influence of audit committees' characteristics on financial risk, which was decomposed into credit risk and liquidity risk. Model 1 emphasized on the effect of audit committees' characteristics on credit risk while model 2 explained the effect of audit committees' characteristics on liquidity risk. Breusch and Pagan Lagrangian multiplier test was carried out to check whether OLS was an appropriate model. The null hypothesis was strongly rejected at Prob $>$ chibar $2=0.0000$ for the models. Furthermore, Hausman test was conducted to compare the appropriate model between fixed effect and random effect estimator. Table 5 revealed that Model 1 accepted the null hypothesis of random individual effects, in which Model 2 also accepted the null hypothesis of random individual effects.

From Table 4, the R squared revealed that $36 \%$ of the systematic variation in the dependent variable were explained by the independent variables in Model 1. From the four hypotheses formulated, only one hypothesis revealed a significant outcome; $\mathrm{p}<0.10$, which was Audit committee accounting expertise. With respect to Audit Committee Accounting Expertise, there was a negative significant relationship between the accounting expertise in the audit committee and credit risk. This revealed that Accounting Expertise in Audit Committees are likely to involve in activities and practices to curb the financial risk.

Table 4. Static Panel Data Analysis of Financial Risk and Audit Committees' Characteristics

\begin{tabular}{lcccccc}
\hline & $\begin{array}{c}\text { MODEL 1 } \\
\text { OLS }\end{array}$ & FE & RE & OLS & FE & RE \\
\hline$A C A E$ & $0.921^{* * *}$ & -0.131 & $-0.155^{*}$ & -0.0850 & 0.0640 & -0.0153 \\
& $(0.347)$ & $(0.0786)$ & $(0.0819)$ & $(0.0982)$ & $(0.128)$ & $(0.104)$ \\
\multirow{2}{*}{$A C M E$} & & & & & 0.0473 \\
& -0.258 & -0.00171 & -0.0154 & 0.0734 & 0.0318 & $(0.0694)$ \\
\multirow{2}{*}{$A C I$} & $(0.250)$ & $(0.0480)$ & $(0.0505)$ & $(0.0708)$ & $(0.0781)$ & -0.0480 \\
& & & & & -0.148 & $(0.362)$ \\
& -0.982 & -0.00871 & 0.0501 & 0.0453 & $(0.467)$ & -0.0631 \\
\hline
\end{tabular}




\begin{tabular}{|c|c|c|c|c|c|c|}
\hline & $(0.326)$ & $(0.108)$ & $(0.113)$ & $(0.0922)$ & $(0.175)$ & $(0.115)$ \\
\hline SIZE & $\begin{array}{c}0.394 * * * \\
(0.108)\end{array}$ & $\begin{array}{c}1.345 * * * \\
(0.173)\end{array}$ & $\begin{array}{c}1.035 * * * \\
(0.146)\end{array}$ & $\begin{array}{l}-0.0473 \\
(0.0307)\end{array}$ & $\begin{array}{l}0.0694 \\
(0.281)\end{array}$ & $\begin{array}{l}-0.0482 \\
(0.0436)\end{array}$ \\
\hline LEV & $\begin{array}{c}0.181 \\
(3.360)\end{array}$ & $\begin{array}{c}0.00843 \\
(2.161)\end{array}$ & $\begin{array}{c}-0.00859 \\
(0.0738)\end{array}$ & $\begin{array}{l}-0.0442 \\
(0.114)\end{array}$ & $\begin{array}{l}-0.0703 \\
(0.114)\end{array}$ & $\begin{array}{l}-0.0659 \\
(0.106)\end{array}$ \\
\hline Constant & $\begin{array}{c}15.58 * * * \\
(3.360)\end{array}$ & $\begin{array}{c}0.382 \\
(2.161)\end{array}$ & $\begin{array}{l}3.982 * * \\
(1.993)\end{array}$ & $\begin{array}{l}1.607 * \\
(0.950)\end{array}$ & $\begin{array}{c}0.717 \\
(3.517)\end{array}$ & $\begin{array}{l}1.906^{*} \\
(1.139)\end{array}$ \\
\hline Observations & 99 & 99 & 99 & 100 & 100 & 100 \\
\hline R-squared & 0.339 & 0.508 & 0.357 & 0.068 & 0.013 & 0.324 \\
\hline RMSE & 2.341 & 0.357 & 0.377 & 0.662 & 0.580 & 0.570 \\
\hline F-test & 7.874 & 12.54 & & 1.116 & 0.161 & \\
\hline Prob > F & 0.000 & 0.000 & & 0.000 & 0.000 & \\
\hline chi-squared & & & 61.58 & & & 2.490 \\
\hline Prob > chi2 & & & 0.000 & & & 0.000 \\
\hline
\end{tabular}

Source: Authors' Survey (2018)

Standard errors in parentheses*** $\mathrm{p}<0.01, * * \mathrm{p}<0.05, * \mathrm{p}<0.1$

Again, Audit Committees' Meeting tends to reduce also any practices that might lead to credit risk in the firms. While both Audit Committee Independence and Audit Committee Gender were attributed positively to the credit risk. The result was in line with Zango, Kamardin and Ishak (2016) findings that asserted a positive relationship between audit committee gender and financial risk.

In addition, Model 2 revealed the effect of Audit Committee's Characteristics on Liquidity Risk. Among all the formulated hypotheses, no hypothesis was significant. However, Audit Committee Accounting Expertise, Audit Committee Independence and Audit Committee Gender have a negative influence on liquidity risk. This asserted that Audit Committee Accounting Expertise, Audit Committee Independence and Audit Committee Gender thrived to curb any evidence of liquidity risk in the firms. The finding was consistent with Farber, Huang and Mauldin (2016), which revealed audit committees with accounting expertise have lower liquidity risk. While the Audit Committee Meeting contributed positively to liquidity risk.

Table 5. Test Cross-Section Fixed and Random Effects

\begin{tabular}{lccclccc}
\hline MODEL 1 & \multicolumn{7}{c}{ MODEL 2 } \\
\hline Summary & Chi-Sq. & Chi-Sq. d.f. & Prob. & Summary & Chi-Sq. & Chi-Sq. d.f. & Prob. \\
$\begin{array}{l}\text { Cross-section } \\
\text { fixed }\end{array}$ & 10.32 & 4 & 0.1117 & $\begin{array}{l}\text { Cross-section } \\
\text { random }\end{array}$ & 2.34 & 4 & 0.8863 \\
\hline
\end{tabular}

Source: Authors' Survey (2018)

\section{Conclusion and Recommendation}

This study examined the relationship that exists between audit committee characteristics and risk management of some selected listed firms in a developing country like Nigeria. The study made use of secondary data to describe the dependent variable (financial risk decomposed into credit risk and liquidity risk) and the explanatory variables (decomposed into audit committee accounting expertise, audit committee meetings, audit committee independence and audit committee gender).

The empirical findings revealed a negative relationship between audit committee accounting expertise and financial risk. The presence of accounting experts in audit committee is paramount as these experts are grounded in knowledge 
required to manage risk. Although there were insignificant, audit committee's independence and female gender have negative relationship with liquidity risk while meeting held by the audit committee had negative relationship with the credit risk.

This study, therefore, recommends that Audit committees should embrace Enterprise Risk Management (ERM) in order to manage risks effectively across the organization. Risk management processes should be one of the major points of discussion during audit committee meetings. There should be a clear line of distinction in organizations of the role of risk management committees and audit committee as regard risk. Members of the audit committee should have a good knowledge of risk management in order to ensure improved performance of the organization. Audit committee meetings should be held often than usual as it provides a platform for discussion about the organizations' risk management. The board of directors should regularly appoint female members to join the audit committee.

\section{Reference}

Akhor, S. O., \& Oseghale, E. O. (2017). An Empirical Investigation of Audit Committee Attributes and Financial Reporting Lag in Nigeria Banking Sector. Journal of Accounting and Financial Management, 3(2).

Alzharani, A. M., \&Aljaaidi, K. S. (2015). An Empirical Investigation of Audit Committee Effectiveness and Risk Management: Evidence from Saudi Arabia. Accounting and Taxation Journal, 7(1).

Beasley, M. (2010). Audit Committee Involvement in Risk Management Oversight: Embracing Emerging Expectations for Risk Management Leadership. Retrieved on 14/10/2017 from www.aicpa.org.

DeZoort, F. T., Hermanson, D. R., Archambeault, D. S., \& Reed, S. A. (2002). Audit Committee Effectiveness: A Synthesis of the Empirical Audit Committee Literature. Journal of Accounting Literature, 21, 39-75.

Disharoon, J. (2015). Audit Committees: The Roles and Responsibilities. Retrieved on 23/09/2017 from www.GRFblog.com

Edogbanya, A., \& Kamardin, H. (2015). The Relationship between Audit and Risk Management Committees on Financial Performance of Non-Financial Companies in Nigeria: A Conceptual Review. Mediterranean Journal of Social Sciences, 6(3). https://doi.org/10.5901/mjss.2015.v6n3p206

Farber, D. B., Huang, S. X., \& Mauldin, E. (2016). Audit Committee Accounting Expertise, Analyst Following and Market Liquidity. Journal of Accounting, Auditing \& Finance, 33(2). https://doi.org/10.1177/0148558X16663090

Guo (2017). Heavy-tailed Distributions and Risk Management of Equity Market Tail Events, Journal of Risk \& Control, 4(1), 31-41. https://doi.org/10.2139/ssrn.3013749

Hamdan, A. M., Mushtaha, S. M., \& Al-Sartawi, A. A. (2013). The Audit Committee Characteristics and Earnings Quality: Evidence from Jordan. Australasian Accounting, Business and Finance Journal, 7(4), 51-80. https://doi.org/10.14453/aabfj.v7i4.5

Jeanroy, L. (2015). The Role of the Audit Committee in Risk Management. Retrieved on 19/10/2017 from www.pem.co.uk

KPMG (2008). Audit Committee Quarterly, Issue 11. Retrieved on 24/02/2018 from https://assets.kpmg.com/content/dam/kpmg/be/pdf/Audit-Committee-Quarterly-Issue-11.pdf

KPMG (2013). Global Audit Committee Survey. Audit Committee Institute.

Ojeka, S. A., Fakile, A. S., Anijesu, A., \& Owolabi, F. (2016). Examining the Quality of Financial Reporting in the Banking Sector in Nigeria: Does Audit Committee Accounting Expertise Matter? Journal of Internet Banking and Commerce, 21(3).

Owolabi, S. A., \& Dada, S. O. (2011). Audit Committee: An Instrument of Effective Corporate Governance. European Journal of Economics, Finance and Administrative Services, issue 35.

Sherman, H. D., Carey, D., \& Robert, B. (2009). Tool Kit The Audit Committee' s New Agenda. Havard Business Review, 190-199.

Verschoor, C. C. (2002). 'Reflections on the audit committee's role', Internal Auditor, April.

Yatim, P. (2009). Audit committee characteristics and risk management of Malaysian listed Firms. Malaysian Accounting Review, 8(1), 19-36.

Zango, A. G., Kamardin, H., \& Ishak, R. (2016). Audit Quality, Board Gender and Financial Risk Disclosure. 
International Journal of Economics and Financial Issues, 6(4). http://www.dx.doi.org/10.2139/ssrn.387561

Zalata, A. M., Tauringana, V., \& Tingbani, I. (2018). Audit Committee Financial Expertise, Gender and Earnings Management: Does Gender of the Financial Expert Matter? International Review of Financial Analysis, 55, 170-183. https://doi.org/10.1016/j.irfa.2017.11.002

\section{Copyrights}

Copyright for this article is retained by the author(s), with first publication rights granted to the journal.

This is an open-access article distributed under the terms and conditions of the Creative Commons Attribution license (http://creativecommons.org/licenses/by/4.0/). 